\title{
The Factors Affecting Quality of Education for Children With Multiple Disabilities in Hanoi and Ho Chi Minh City of Vietnam
}

\author{
Hoang Thi Nho \\ Hanoi National University of Education, Hanoi, Vietnam \\ Cao Thi Xuan My \\ Ho Chi Minh University of Education, Ho Chi Minh city, Vietnam
}

\begin{abstract}
This paper studied the factors that influenced education and care qualitiy for 33 children with multiple disabilities from 5 to 13 years old. Those children were assessed by using communication and learning assessment, and 33 teachers were also interviewed by questionnaires. The results of the study indicated that the biggest difficulties in all children with multiple disabilities in both Hanoi and Ho Chi Minh cities are communication skills, the lack of communication symbol system, inappropriate approaches from their parents and teachers in educating and taking care of children with multiple disabilities, and weak collaboration and partnership among educational forces.
\end{abstract}

Keywords: children with multiple disabilities, qualify of education, communication

\section{Introduction}

In recent years, there has been increasing recognition that children with multiple disabilities and visual impairments constitute a distinct group with a unique set of educational needs. In former days, children now being described as having profound or severe learning disabilities may have been classified as "uneducable" and were consigned to local health care, or did not attend any special form of attention.

Classification of children into categories, according to their primary handicap, tends to restrict the recognition of other problems that the child might have. Then, "mental handicap" tends to be viewed as the primary disability and gradually takes precedence over additional sensory impairments in decisions about educational placements.

In education, it is better to replace the idea of categories of handicaps by a consideration of the needs of the individuals.

Multiple impairments or concomitant impairments, such as mentally retarded-blind, mentally retarded-orthopedically impaired, etc., the combination of which causes such severe educational problems that they cannot be accommodated in special education programs solely for one of the impairments. The term does not include deaf-blind children.

The essential feature of multiple disabilities (term used by Orelove \& Sobsey, 1991, as cited in Mason \& McCall, 2001) is the fusion or interaction of the disabilities and their combined influence on development. The

Hoang Thi Nho, Ph.D., Faculty of Special Education, Hanoi National University of Education.

Cao Thi Xuan My, Ph.D., Head Section, Faculty of Special Education, Ho ChiMinh University of Education. 
term usually refers to individuals with severe or profound learning disabilities or one or more significant motor or sensory impairments and/or special health care need.

\section{Literature Review}

The tem "situation" is used rather than "condition," in which the situation is characterized by an individual being unable to (Best \& Brown, 1994, as cited in Mason \& McCall, 2001) "gather sufficient information from the environment to learn independently" or "make sufficient use of the environment to function independently."

The needs of these children cannot be considered in isolation from the more extensive needs of the family as a social group. Caring for children with special needs inevitably results in changes in families' roles, and this may produce additional tensions and conflicts. What parents want for their child may be quite different from the goals identified by professionals. Any assessment of the child, therefore, should consider not only the child's individual educational needs, but also the needs of the child within a wider context of the family.

To ensure that children with multiple impairments and visual impairments are able to live as full and normal a life as possible, the following needs can be identified (from New Direction, Royal National Institute for the Blind [RNIB], 1990, as cited in Mason \& McCall, 2001):

(a) early identification and diagnosis of visual impairment;

(b) accurate assessment of performances and abilities;

(c) appropriate formal education from the earliest possible age;

(d) training in making full use of residual vision;

(e) access to a wide range of expertise.

There is no single assessment instrument possesses that all desirable characteristics (cognitive, adaptive, social, or linguistic aspects of development) are necessary to be measured in a multiimpaired child with visual impairment. Very few measures are available that have been designed specifically with visually impaired children in mind.

One should not even attempt to assess the child with a visual impairment without any awareness of the impact a visual disturbance has upon all areas of development.

Children with multiple disabilities and visual impairments encounter diverse challenges in their development of communication skills. Complex sensory, physical, and cognitive impairments may make conventional means of interpersonal communication inaccessible to or inappropriate for this population.

The incidence of communication difficulty in children with visual impairments and additional disabilities is higher than that in children with visual impairments and no additional disabilities.

The incidence of language disorder in children with visual impairments is higher than that in the population of sighted children.

The development of communication skills is of highest priority in enabling children to access other curriculum areas.

Communication should be viewed as a two-way process. There are various strategies involving the use of different forms of communication that may be used to aid the child's understanding.

A thorough evaluation of a child's informal communication strategies is of great importance and intervention strategies should vary depending on the child's needs.

Considerable consensus exists around the basic dimensions of quality education today. However, quality education as United Nations International Children’s Emergency Fund (UNICEF) (2000) defined: 
Learners who are healthy, well-nourished, and ready to participate and learn, and supported in learning by their families and communities; environments that are healthy, safe, protective, and gender-sensitive, and provide adequate resources and facilities; content that is reflected in relevant curricula and materials for the acquisition of basic skills, especially in the areas of literacy, numeracy, and skills for life and knowledge in such areas as gender, health, nutrition, Human Immunodeficiency Virus (HIV/AID) sprevention, and peace; processes through which trained teachers use child-centred teaching approaches in well-managed classrooms and schools and skillful assessment to facilitate learning and reduce disparities; and outcomes that encompass knowledge, skills, and attitudes that are linked to national goals for education and positive participation in society.

\section{Research Arrangement}

Ho Chi Minh city and Hanoi are two biggest cultural and economic centers in Vietnam. The research questionnaires were distributed to teachers of children with multiple disabilities in three special schools for children with multiple disabilities: Khanh An Special School (Hanoi), Nhat Hong Special School (Ho Chi Minh city), and Nguyen Dinh Chieu School (Ho Chi Minh city).

Thirty-three answered questionnaires were received in total (see Table 1), and there are 26 teachers (78.8\%) graduating at Bachelor level (BA level), among whom 23 teachers (69.9\%) have 4 to 20 years experience in teaching children.

Table 1

Percent (\%) of Questionnaires at Four Schools

\begin{tabular}{lcl}
\hline School/Institution & Questionnaires & Percent (\%) \\
\hline Khanh An Special School (Hanoi) & 16 & 48.50 \\
Nhat Hong Kindergarten (Ho Chi Minh city) & 4 & 12.20 \\
Nguyen Dinh Chieu (Ho Chi Minh city) & 13 & 39.30 \\
\hline
\end{tabular}

There are only few special schools for children with multiple disabilities in Ho Chi Minh city and Hanoi in Vietnam. For this reason, the patterns from the schools, not only represent Ho Chi Minh city and Hanoi, but also Vietnam (see Table 1).

Table 2

Number of Children With Multiple Disabilities in the Class

\begin{tabular}{llcc}
\hline No. & Number of children with multiple disabilities & Frequency $(N)$ & Percent $(\%)$ \\
\hline 1 & 3 & 1 & 3.00 \\
2 & 5 & 1 & 3.00 \\
3 & 6 & 4 & 12.10 \\
4 & 7 & 2 & 6.10 \\
5 & 8 & 6 & 18.20 \\
6 & 9 & 3 & 9.10 \\
7 & 10 & 1 & 3.00 \\
8 & 11 & 11 & 33.30 \\
9 & 12 & 1 & 3.00 \\
10 & 13 & 1 & 3.00 \\
11 & 16 & 2 & 6.10 \\
& Total & 33 & 100.00 \\
\hline
\end{tabular}

Table 2 shows that there are two (6.1\%) teachers teaching in the class with 16 children with multiple disabilities and about 11 (33.3\%) teachers are teaching in the class with 11 children with multiple disabilities. 
The data show that the number of children with multiple disabilities is quite a large group. Teachers have quite a lot of works to deal with most classes with only two teachers.

Table 3 shows that there are 12 (36.4\%) teachers having only 0.5 years experiences in teaching children with multiple disabilities, five (15.2\%) teachers 2 years experiences, and 11 (33.3\%) teachers in total 4 to 15 years experiences. Therefore, it can be concluded that there are many teachers not having enough experience in teaching children with multiple disabilities. Moreover, the teachers who are experienced and well trained are mostly in the south of Vietnam.

Table 3

The Years of Teaching Children With Multiple Disabilities in the Class

\begin{tabular}{lccc}
\hline No. & Years & Frequency $(N)$ & Percent $(\%)$ \\
\hline 1 & 0.50 & 12 & 36.40 \\
2 & 1.00 & 1 & 3.00 \\
3 & 1.50 & 3 & 9.10 \\
4 & 2.00 & 5 & 15.20 \\
5 & 3.00 & 1 & 3.00 \\
6 & 4.00 & 1 & 3.00 \\
7 & 5.00 & 2 & 6.10 \\
8 & 6.00 & 2 & 6.10 \\
9 & 8.00 & 1 & 3.00 \\
10 & 9.00 & 1 & 3.00 \\
11 & 10.00 & 2 & 6.10 \\
12 & 11.00 & 1 & 3.00 \\
13 & 15.00 & 1 & 3.00 \\
& Total & 33 & 100.00 \\
\hline
\end{tabular}

\section{The Evaluation From Teachers About the Factors Affecting Quality of Education for Children With Multiple Disabilities}

\section{Importance Level of the Factors in Care and Education for Children With Multiple Disabilities}

Table 4

The Importance Level of the Factors in Care and Education for Children With Multiple Disabilities $(N=33)$ (Min. = 1; Max. = 4)

\begin{tabular}{lllll}
\hline Content & Sum. & $\bar{X}$ & $S D$ & Ranking \\
\hline Educational and caring program & 121 & 3.69 & 0.46 & 3 \\
Conditions of physical facilities, teaching facilities, and learning materials & 114 & 3.48 & 0.57 & 8 \\
Communication environment & 119 & 3.63 & 0.49 & 4 \\
The education qualification of teachers & 123 & 3.75 & 0.44 & 1 \\
Learning styles of children with multiple disabilities & 109 & 3.33 & 0.74 & 10 \\
Experiences on children with multiple disabilities & 112 & 3.42 & 0.66 & 9 \\
Method of teachers in communication, care, and education & 119 & 3.63 & 0.65 & 4 \\
Frequency of communication, care, education of teachers & 122 & 3.72 & 0.59 & 2 \\
Attitudes and expectations of parents, teachers, and children with multiple & 108 & 3.30 & 0.49 & 11 \\
$\quad$ disabilities & 100 & 3.06 & 0.47 & 12 \\
Supporting from the community & 119 & 3.63 & 0.56 & 4 \\
Coordinating in care and education between families and schools & 115 & 3.50 & 0.37 & \\
$X_{\text {total }}$ & &
\end{tabular}


Table 4 shows that, according to the evaluation from teachers, the most important factors impact care and educational processes for children with multiple disabilities are "the education qualification of teachers" $(\bar{X}=$ 3.75), "frequency of communication, care, and education of teachers" $(\bar{X}=3.72)$, and "Educational and caring program" $(\bar{X}=3.69)$. However, teachers had made the choice for the importance level of the factors without consideration of these factors, such as attitudes, expectations of parents, teachers, and children with multiple disabilities, and supporting from the community. It also indicates that teachers are not yet concerning much about the supporting from others.

\section{Conditions of High Quality Care and Education for Children With Multiple Disabilities}

Table 5

Conditions of High Quality Care and Education for Children With Multiple Disabilities ( $N=33)$ (Min. = 1; Max. = 5)

\begin{tabular}{|c|c|c|c|c|}
\hline Advantages & Sum. & $\bar{X}$ & $S D$ & Ranking \\
\hline Being able to communicate with children & 148 & 4.51 & 0.26 & 1 \\
\hline Receiving the support from schools & 145 & 4.42 & 0.57 & 2 \\
\hline Having been trained on education for children with multiple disabilities & 136 & 4.15 & 0.49 & 3 \\
\hline Knowing how to use the supporting tactile materials & 120 & 3.66 & 0.44 & 5 \\
\hline $\begin{array}{l}\text { Being able to develope Individualized Education Program (IEP) for children } \\
\text { with multiple disabilities }\end{array}$ & 119 & 3.63 & 0.74 & 6 \\
\hline $\begin{array}{l}\text { Knowing how to find information on internet about education for children } \\
\text { with disabilities }\end{array}$ & 133 & 4.06 & 0.66 & 4 \\
\hline Supporting from other members in the community & 136 & 4.15 & 0.65 & 3 \\
\hline$X_{\text {total }}$ & & 4.08 & & \\
\hline
\end{tabular}

Table 5 shows that most teachers have made the evaluation that the best quality conditionsin caring and education for children with multiple disabilities children are "being able to communicate with children” $(\bar{X}=$ 4.51), "receiving support from schools" $(\bar{X}=4.42)$, "having been trained on education for children with multiple disabilities" ( $\bar{X}=4.15)$, and "supporting from other members in the community" $(\bar{X}=4.15)$. However, teachers had made their choices for the factors not being important, such as "knowing how to use the supporting tactile materials" $(\bar{X}=3.66)$, "being able to develope IEP for children with multiple disabilities" $(\bar{X}$ = 3.63), etc.. In fact, teachers do not have many chances to be trained on education for children with multiple disabilities and the supporting of other educational members is not strong.

\section{The Difficulties in Care and Education for Children With Multiple Disabilities}

Table 6

The Difficulties in Care and Education for Children With Multiple Disabilities $(N=33)($ Min. $=1$; Max. $=4)$

\begin{tabular}{|c|c|c|c|c|}
\hline Difficulties & Sum. & $\bar{X}$ & $S D$ & Ranking \\
\hline Children lack experiences & 113 & 3.45 & 0.66 & 2 \\
\hline Children taking a long time to understand the meaning of communication & 109 & 3.33 & 0.66 & 5 \\
\hline Children unable to know how to ask for help when need & 113 & 3.45 & 0.75 & 2 \\
\hline Children unable to walk independently & 105 & 3.21 & 0.98 & 8 \\
\hline Lack of suitable materials for children with multiple disabilities & 110 & 3.36 & 1.36 & 4 \\
\hline No communication system for children with multiple disabilities & 104 & 3.18 & 0.89 & 6 \\
\hline No ideas about how to assess the needs of children with multiple disabilities & 109 & 3.33 & 1.09 & 5 \\
\hline No ideas about how to develop an IEP for a child with multiple disabilities & 102 & 3.12 & 0.60 & 8 \\
\hline Weak collaborations between the therapists, teachers, and parents & 114 & 3.48 & 0.45 & 1 \\
\hline$X_{\text {total }}$ & & 3.32 & & \\
\hline
\end{tabular}


Table 6 shows that the biggest difficulty for teachers is "weak collaborations between the therapists, teachers, and parents" $(\bar{X}=3.48)$, and the others concern to "lack of suitable materials for children with multiple disabilities” $(\bar{X}=3.36)$. It indicats that most activities in education for children with multiple disabilities in both cities are not well involved by the other members, such as parents, therapists, and other supporting staffs in schools and community.

\section{The Time for Activities Spent by Teachers for the Whole Week on Care and Education for Children With Multiple Disabilities}

Table 7

The Periods of Time of Activities Spent by Teachers in a Week $(N=33)$

\begin{tabular}{lll}
\hline No. & Activities & Time costed (hours/week) \\
\hline 1 & Prepare and modify teaching materials for children with multiple disabilities & 4.00 \\
2 & Support children with multiple disabilities in individual sessions & 6.03 \\
3 & Provide communication guidance for children & 5.45 \\
4 & Evaluate and adjust content of IEP & 5.04 \\
5 & Exchange ideas with parent about the children's progress and related activities & 2.19 \\
6 & Exchange ideas with administration and colleges about the children's progress and related activities 1.75 \\
\hline
\end{tabular}

Table 7 shows that the longest time spent by teachers is supporting individual sessions for children with multiple disabilities $(\bar{X}=6.03)$. The least time teachers spent in exchanging ideas with administration and colleges $(\bar{X}=1.75)$. It points out that teachers and other educational forces should collaborate and cooperate more frequently to improve the quality of care and education for children with multiple disabilities.

Table 8

The Time for Preparation and Adaption of Teaching Material Spent by Teachers in a Week $(N=33)$

\begin{tabular}{lccc}
\hline No. & Time costed (hours/week) & Frequency $(N)$ & Percent $(\%)$ \\
\hline 1 & 1.00 & 5 & 15.2 \\
2 & 2.00 & 15 & 45.5 \\
3 & 3.00 & 4 & 12.1 \\
4 & 4.00 & 3 & 9.1 \\
5 & 5.00 & 3 & 9.1 \\
6 & 8.00 & 1 & 3.0 \\
7 & 10.00 & 1 & 3.0 \\
8 & 40.00 & 1 & 3.0 \\
Total & & 33 & 100.0 \\
\hline
\end{tabular}

Table 8 shows that most (45.5\%) teachers spend only two hours on preparing and adapting teaching material for children with multiple disabilities and only three (9.1\%) teachers spend more than eight hours on preparing and adapting teaching material for children with multiple disabilities. It points out that teachers should spend more time on preparing material for teaching children with multiple disabilities.

\section{Teacher's Effectiveness Evaluation on Activities in Care and Education for Children With Multiple Disabilities}

Table 9 shows that the most effective activity evaluated by teachers is choosing and adjusting teaching content to meet the needs of children $(\bar{X}=3.45)$. The lower values of effectiveness are finding out their children's learning interests $(\bar{X}=3.18)$ and using tactile materials in communication $(\bar{X}=3.18)$. These activities are very important in working effectively with children with multiple disabilities. 
Table 9

Teacher's Effectiveness Evaluation on Activities in Care and Education for Children With Multiple Disabilities $(N=33)($ Min. $=1 ;$ Max. $=4)$

\begin{tabular}{lllll}
\hline Activities & Sum. & $\bar{X}$ & $S D$ & Ranking \\
\hline Gather information about children & 108 & 3.30 & 0.55 & 4 \\
Find out children's experiences, hobbies, and needs & 112 & 3.42 & 0.56 & 2 \\
Identify children's learning styles and developmental stages & 108 & 3.30 & 0.58 & 4 \\
Identify children's education goals & 110 & 3.36 & 0.51 & 3 \\
Choose and adjust teaching content to meet the needs of children & 113 & 3.45 & 0.66 & 1 \\
Use tactile materials in communication & 104 & 3.18 & 0.89 & 7 \\
Provide information for children with different sensory inputs & 108 & 3.30 & 0.72 & 4 \\
Find out their children's learning interests & 104 & 3.18 & 0.66 & 7 \\
$X_{\text {total }}$ & & 3.30 & & \\
\hline
\end{tabular}

\section{The Assessment Results on Capacity of Children With Multiple Disabilities}

The assessment was made with 33 children of the age 5 to 13 years old with multiple disabilities in Ho Chi Minh city and Hanoi.

Table 10

The Assessment Results on Capacity of Children With Multiple Disabilities ( $N=33)$

\begin{tabular}{|c|c|c|c|c|c|c|}
\hline \multirow[b]{2}{*}{ Contents } & \multicolumn{2}{|c|}{ Good } & \multicolumn{2}{|c|}{ Medium } & \multicolumn{2}{|c|}{ Weak } \\
\hline & $\begin{array}{l}\text { Frequency } \\
(N)\end{array}$ & Percent (\%) & $\begin{array}{l}\text { Frequency } \\
(N)\end{array}$ & Percent (\%) & $\begin{array}{l}\text { Frequency } \\
(N)\end{array}$ & Percent (\%) \\
\hline Identification of material texture & 18 & 54.40 & 12 & 36.40 & 3 & 9.10 \\
\hline $\begin{array}{l}\text { Perception of speech, vocalization, or } \\
\text { environmental sounds }\end{array}$ & 20 & 60.60 & 13 & 39.40 & 7 & 6.70 \\
\hline Vowel sounds, consonant-vowel pairs & 17 & 51.70 & 1 & 3.00 & 15 & 45.30 \\
\hline Vocalizations (cry, coo, babble, and gurgle) & 23 & 69.70 & 1 & 3.00 & 9 & 27.30 \\
\hline Spoken words & 14 & 42.10 & 8 & 24.30 & 11 & 33.30 \\
\hline Facial expressions & 15 & 45.50 & 9 & 27.30 & 9 & 27.30 \\
\hline Gesture & 12 & 36.40 & 11 & 33.30 & 10 & 30.30 \\
\hline Eye gaze & 6 & 18.20 & 5 & 15.20 & 22 & 66.70 \\
\hline Manual sign & 3 & 9.10 & 2 & 6.10 & 28 & 84.80 \\
\hline Object symbols & 3 & 9.10 & 4 & 12.10 & 26 & 78.80 \\
\hline Picture symbols & 3 & 9.10 & 2 & 6.10 & 28 & 84.80 \\
\hline Tactile Symbols & 5 & 15.20 & 2 & 6.10 & 26 & 78.80 \\
\hline Use of "high-tech" communication devices & 4 & 12.10 & 11 & 33.30 & 18 & 54.60 \\
\hline Handling/touch/movement & 7 & 21.20 & 10 & 30.30 & 16 & 48.50 \\
\hline Tactile (hand-in-hand) signs & 4 & 12.20 & 3 & 9.10 & 26 & 79.70 \\
\hline Specifics tough & 4 & 12.20 & 7 & 21.20 & 22 & 56.70 \\
\hline
\end{tabular}

Table 10 shows that the biggest challenges of children with multiple disabilities are "manual sign," "object symbols," "picture symbols," "tactile symbols," and "use of "high-tech" communication devices.” Up to 84.4\% children have difficulty in picture symbols and manual sign. In this survey samples, most children have been learning at schools/centers about more than three years and this rate shows that the system of symbols to communicate with children are not fully concerned. 


\section{Linear Regression Between the Factors Affecting Quality of Education for Children With Multiple Disabilities}

The linear regression below (see Tables 11, 12, 13, \& 14) shows that the most effective factors influence the assessment results on capacity of children with multiple disabilities are finding out children's interests in learning, exchanging ideas with administration and colleges about the children's progress and related activities, and having no communication system for children with multiple disabilities.

Table 11

\section{Correlations}

\begin{tabular}{|c|c|c|c|c|c|c|c|}
\hline & & $\begin{array}{l}\text { Cognition } \\
\text { development }\end{array}$ & $\begin{array}{l}\text { Children taking } \\
\text { a long time to } \\
\text { understand the } \\
\text { meaning of } \\
\text { communication }\end{array}$ & $\begin{array}{l}\text { No } \\
\text { communicatio } \\
\text { n system for } \\
\text { multiple } \\
\text { disabled } \\
\text { children } \\
\end{array}$ & $\begin{array}{l}\text { Identifing } \\
\text { children's } \\
\text { education } \\
\text { goals }\end{array}$ & $\begin{array}{l}\text { Children's } \\
\text { gender }\end{array}$ & $\begin{array}{l}\text { Total evaluation } \\
\text { of comnimucation } \\
\text { by tactile } \\
\text { (hand-in-hand) } \\
\text { signs and } \\
\text { specifics tough }\end{array}$ \\
\hline \multirow{3}{*}{ Cognition development } & $\begin{array}{l}\text { Pearson } \\
\text { correlation }\end{array}$ & 1 & $0.367^{*}$ & 0.049 & $0.579^{* *}$ & -0.217 & $-0.395^{*}$ \\
\hline & Sig. (2-tailed) & & 0.035 & 0.787 & 0.000 & 0.225 & 0.023 \\
\hline & $N$ & 33 & 33 & 33 & 33 & 33 & 33 \\
\hline \multirow{3}{*}{$\begin{array}{l}\text { Children taking a long } \\
\text { time to understand the } \\
\text { meaning of } \\
\text { communication }\end{array}$} & $\begin{array}{l}\text { Pearson } \\
\text { correlation }\end{array}$ & $0.367^{*}$ & 1 & $0.599^{* *}$ & $0.578^{* *}$ & 0.089 & $-0.580^{* *}$ \\
\hline & Sig. (2-tailed) & 0.035 & & 0.000 & 0.000 & 0.624 & 0.000 \\
\hline & $N$ & 33 & 33 & 33 & 33 & 33 & 33 \\
\hline \multirow{3}{*}{$\begin{array}{l}\text { No communication } \\
\text { system for children with } \\
\text { multiple disabilities }\end{array}$} & $\begin{array}{l}\text { Pearson } \\
\text { correlation }\end{array}$ & 0.049 & $0.599^{* *}$ & 1 & $0.538^{* *}$ & -0.010 & $-0.381^{*}$ \\
\hline & Sig. (2-tailed) & 0.787 & 0.000 & & 0.001 & 0.957 & 0.029 \\
\hline & $N$ & 33 & 33 & 33 & 33 & 33 & 33 \\
\hline \multirow{3}{*}{$\begin{array}{l}\text { Identifing children's } \\
\text { education goals }\end{array}$} & $\begin{array}{l}\text { Pearson } \\
\text { correlation }\end{array}$ & $0.579^{* *}$ & $0.578^{* *}$ & $0.538^{* *}$ & 1 & 0.030 & $-0.380^{*}$ \\
\hline & Sig. (2-tailed) & 0.000 & 0.000 & 0.001 & & 0.870 & 0.029 \\
\hline & $N$ & 33 & 33 & 33 & 33 & 33 & 33 \\
\hline \multirow{3}{*}{ Children’s gender } & $\begin{array}{l}\text { Pearson } \\
\text { correlation }\end{array}$ & -0.217 & 0.089 & -0.010 & 0.030 & 1 & $0.401^{*}$ \\
\hline & Sig. (2-tailed) & 0.225 & 0.624 & 0.957 & 0.870 & & 0.021 \\
\hline & $N$ & 33 & 33 & 33 & 33 & 33 & 33 \\
\hline \multirow{3}{*}{$\begin{array}{l}\text { Total evaluation of } \\
\text { comnimucation by tactile } \\
\text { (hand-in-hand) signs and } \\
\text { specifics tough }\end{array}$} & $\begin{array}{l}\text { Pearson } \\
\text { correlation }\end{array}$ & $-0.395^{*}$ & $-0.580^{* *}$ & $-0.381^{*}$ & $-0.380^{*}$ & $0.401^{*}$ & 1 \\
\hline & Sig. (2-tailed) & 0.023 & 0.000 & 0.029 & 0.029 & 0.021 & \\
\hline & $N$ & 33 & 33 & 33 & 33 & 33 & 33 \\
\hline
\end{tabular}

Note. ${ }^{*}$ Correlation is significant at the 0.05 level (2-tailed); ${ }^{* *}$ Correlation is significant at the 0.01 level (2-tailed).

Table 12

Model Summary

\begin{tabular}{lllll}
\hline Model & $R$ & $R^{2}$ & Adjusted $R^{2}$ & S.E. \\
\hline 1 & $0.785^{\mathrm{a}}$ & 0.616 & 0.576 & 0.78437 \\
\hline
\end{tabular}

Note. ${ }^{a}$ Predictors (Constant): Find out children's interests in learning; Exchange ideas with administration and colleges about the children's progress and related activities; Do not have communication system for childrenwith multiple-disabilities. 
Table 13

The Univariate Analyses of Variance (ANOVA ${ }^{b}$ )

\begin{tabular}{|c|c|c|c|c|c|c|}
\hline \multicolumn{2}{|c|}{ Model } & \multirow{2}{*}{$\begin{array}{l}\text { Sum of squares } \\
28.580\end{array}$} & \multirow{2}{*}{$\frac{D f}{3}$} & \multirow{2}{*}{$\begin{array}{l}\text { Mean square } \\
9.527\end{array}$} & \multirow[t]{2}{*}{$F$} & \multirow[t]{2}{*}{ Sig. } \\
\hline & Regression & & & & & \\
\hline \multirow[t]{2}{*}{1} & Residual & 17.842 & 29 & 0.615 & 15.485 & $0.000^{\mathrm{a}}$ \\
\hline & Total & 46.422 & 32 & & & \\
\hline
\end{tabular}

Note. ${ }^{\text {a }}$ Predictors (Constant): Find out children's interests in learning; Exchange ideas with administration and colleges about the children's progress and related activities; Do not have communication system for childrenwith multiple-disabilities;

${ }^{\mathrm{b}}$ Dependent variable: assessment results in capacity of children with multiple disabilities.

Table 14

Coefficients $^{a}$

\begin{tabular}{|c|c|c|c|c|c|c|}
\hline \multirow{2}{*}{\multicolumn{2}{|c|}{ Model }} & \multicolumn{2}{|c|}{$\begin{array}{l}\text { Unstandardized } \\
\text { coefficients }\end{array}$} & \multirow{2}{*}{$\begin{array}{l}\begin{array}{l}\text { Standardized } \\
\text { coefficients }\end{array} \\
B\end{array}$} & \multirow[t]{2}{*}{$t$} & \multirow[t]{2}{*}{ Sig. } \\
\hline & & $B$ & S.E. & & & \\
\hline \multirow{4}{*}{1} & (Constant) & 6.463 & 0.815 & & 7.932 & 0.000 \\
\hline & $\begin{array}{l}\text { Do not have communication system for } \\
\text { children with multiple disabilities }\end{array}$ & -0.725 & 0.177 & -0.486 & -4.084 & 0.000 \\
\hline & $\begin{array}{l}\text { Exchange ideas with administration and } \\
\text { colleges about the children's progress } \\
\text { and related activities }\end{array}$ & 0.360 & 0.080 & 0.519 & 4.470 & 0.000 \\
\hline & Find out children’s interests in learning & -0.569 & 0.234 & -0.292 & -2.437 & 0.021 \\
\hline
\end{tabular}

Note. ${ }^{a}$ Dependent variable: Assessment results in capacity of children with multiple disabilities.

\section{The Recommendations From Teachers to Improve Quality of Education for Children With Multiple Disabilities}

Teachers have raised the request to improve education quality for children with multiple disabilities as below:

1. Provide much more facilities to help children to have a less restrictive and free learning environment. The specific equipments need to be updated and modified to meet the needs of children;

2. Give opportunities to teachers in training, sharing experiences, and having supporting system;

3. Create more cooperative and collaborative working networks (speech therapists, psychologists, physical therapists...). There is a weak connection between health services and educational institutions at the moment. Most schools usually lack of therapy works, and the lack of equipment and qualified specialists are the reasons why limitation of the results exists. Moreover, it really needs to have strong cooperation among schools, parents, and community to improve the quality of education for children with multiple disabilities.

\section{Conclusion}

The survey shows that the factors affecting quality of education for children with multiple disabilities are mainly finding out children's interests in learning, sharing ideas with administration and colleges about the children's progress and related activities, having no communication systems for children with multiple disabilities.

It is suggested that the communication systems for children with multiple disabilities should be set up and to be trained for teachers in how to be used effectively.

School and community should have action plans to create a strong cooperation and partnership among teachers, parents, and other supporters to improve education quality for children with multiple disabilities. 
In working with children with multiple disabilities, teachers and supporters should verify and teach them based on their interests that stimulate and motivate them to participate in learning and communication with teachers and peers.

\section{References}

Mason, H., \& McCall, S. (2001). Visual impairment: Access to education for children and young people. London: David Fulton Publishers Ltd..

Rowland, C. (Ed.). (2009). Assessing communication and learning in young children who are deaf, blind, or who have multiple disabilities. Learn Projects of Oregon Health and Science University, Oregon, USA.

Royal National Institute for the Blind (RNIB). (1992). Blind and planning partially sighted children in Britain: The RNIB survey. London, U.K.: Her (His) Majesty's Stationary Office (HMSO). 